\title{
CHEMICAL AND MECHANICAL PROPERTIES OF VELVET TAMARIND FRUIT (DIALIUM GUINEENSE)
}

\author{
F. U. Asoiro ${ }^{1,}{ }^{*}$, S. L. Ezeoha ${ }^{2}$, G. I. Ezenne ${ }^{3}$ and C. B. Ugwu ${ }^{4}$ \\ 1,2,3,4 Dept of Agricultural/Bioresources EngineERING, University OF Nigeria, NSUKKA, ENUGU STATE, NIGERIA. \\ E-mail addresses:1felix.asoiro@unn.edu.ng,2sunday.ezeoha@unn.edu.ng,3gloria.ezenne@unn.edu.ng, \\ ${ }^{4}$ chuggybernard88@yahoo.com
}

\begin{abstract}
Information on chemical properties of fruits is crucial in processing it into different foods. Mechanical properties of fruits determine their susceptibility to mechanical damages that occur during harvest, transportation, and storage; and which eventually lead to a pronounced reduction in commercial value. This study was conducted to investigate the chemical and mechanical properties of unshelled (black), shelled (yellow) and kernel of Dialium guineense fruit. The chemical properties investigated include some proximate and mineral elements. The mechanical properties were bio-yield force, rupture force, deformation at rupture point, deformation ratio at rupture point, compressive strength and total strain energy. The fruit pulp was found to be composed of protein (9.4\%), carbohydrate (75\%), crude fat (5.2\%), crude fibre (4.6\%), and ash content (2.4\%) at 19\% moisture content (wb). The mineral composition of the pulp were sodium (3.2 $\mathrm{g} / \mathrm{kg}$ ), magnesium $(2.9 \mathrm{~g} / \mathrm{kg})$, phosphorus $(0.5 \mathrm{~g} / \mathrm{kg})$, calcium $(0.5 \mathrm{~g} / \mathrm{kg})$, iron $(0.1 \mathrm{~g} / \mathrm{kg})$, and vitamin $C(0.3 \mathrm{~g} / \mathrm{kg})$ at a pH of 3.9. Less force is required to crack the fruit across the length, followed by across the thickness and then across the width. Velvet tamarind (Dialium guineense) fruit pulp is a promising source of food and essential minerals due to its nutritional values, hence facilitating its postharvest processing is inevitable.
\end{abstract}

Keywords: Chemical Properties; Mechanical Properties; Dialium Guineense; Velvet Tamarind; Deformation At Rupture; Ash Content.

\section{INTRODUCTION}

Velvet tamarind (Dialium guineense) is a tree of an average height of $30 \mathrm{~m}$ with densely leafy crown, smooth greyish bark. Leaves are hairy and the flowers are usually whitish while the fruits are less circular and flattened. The pulp of the fruit is edible and sweet, with fairly low levels of ascorbic acid and tannin. It is a fairly good source of protein and minerals [1]. Velvet tamarind (Dialium guineense) can be found in West African countries such as Ghana where it is known as Yoyi, Sierra Leone, Senegal, and Nigeria where it is known as Awin in Yoruba, Icheku in Igbo and Tsamiyar kurm in Hausa [2, 3].

The fruits are widely sold in local markets and are consumed fresh by people of all ages as a snack. Some elderly people consume non-alcoholic drink made from the fruit. Dialium guineense pulp flour is found to have desirable physicochemical and sensory properties which may predispose it as a useful raw material for food industries, especially for the production of highlysought-after candy [4].
In addition, the bark, roots and leaves of Dialium guineense have medicinal properties and are used for the treatment of variety of health problems. The fruits of the plant are chewed by most women in Southeastern Nigeria to improve lactation and check genital infection $[2,3,5]$. The leaves and stem bark are also used as folklore remedies for the treatment of infections such as diarrhoea, severe cough, bronchitis, wound, stomachaches, malaria, fever, jaundice, ulcer and haemorrhoids [6]. The flour of Dialium guineense pulp can be incorporated in infant foods to enhance appetite and provide remedy for the problem of scurvy and micro nutrient deficiencies[7]. Extracts from Dialium guineense plants have been shown to possess both anti-mutagenic and molluscicidal activities [7].

For optimizing equipment design for the mechanization, postharvest processing, storage, harvesting and transportation as well as oil extraction and handling,chemical and mechanical properties of Dialium guineense fruit have to be known. In Nigeria, there is hardly any machine for the mechanization and postharvest processing of Dialium guineense fruit. Most

* Corresponding author, tel: +234-806-358-8320 
postharvest operations involve manual cracking of the pods with bare fingers to bring out the succulent (yellow) pulp, which is quite laborious, time consuming and cumbersome. This has reduced its utilization as a source of revenue for the country both locally and internationally. Despite the huge economic, medicinal, industrial and social importance of this fruit, little is known of its postharvest, physical, chemical and mechanical properties. Many researchers have determined the physical, chemical and mechanical properties of some economic seeds and grains, such as soyabean $[8,9]$, oil bean seeds [10], neem nuts [11], karingda seeds [12], cumin seeds [13], lentil seeds [14], sunflower seeds [15], coffee [16], green gram [17], chick pea seeds [18], African yam beans [19], blueberry [20], but very little information abound on the chemical and mechanical properties of this very important fruit. The objective of this study was therefore to determine some chemical and mechanical properties of velvet tamarind fruit (unshelled, shelled, and the kernel); so as to facilitate its postharvest processing and to enhance the various socioeconomic benefits of the fruit, both to individuals and the nation, and on a global scale.

\section{MATERIALS AND METHODS}

\subsection{Sample Collection and Preparation}

Freshly harvested Dialium guineense fruits were sourced from some local farmers at Ogige market, Nsukka local government area of Enugu state, Nigeria. The fruits were cleaned manually by hand to remove foreign matter such as dust, dirt, pieces of stones, as well as broken and immature fruits. Some of the fruits were manually cracked and grouped. Determination of the mechanical and chemical properties was carried out in Civil Engineering Laboratory and Crop Science Laboratory, respectively in the University of Nigeria, Nsukka. Figure 1 shows the unshelled, shelled and kernel of Dialium guineense fruits.

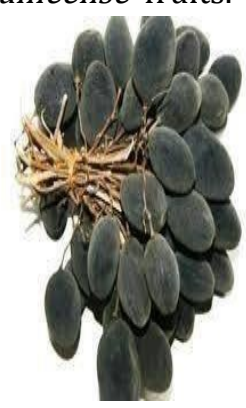

(a) Unshelled

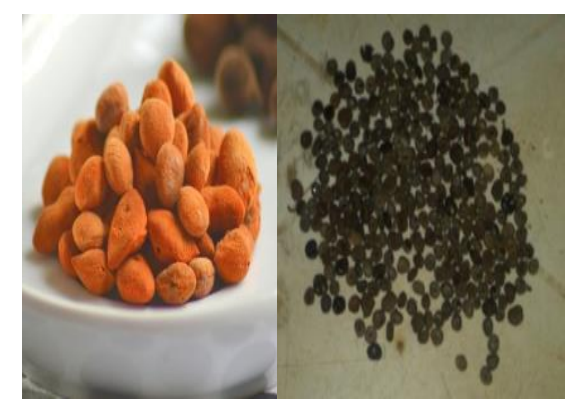

(b) Shelled

...(c) Kernel
Figure 1. Pictorial view of Dialium guineense fruit

\subsection{Determination of Chemical Properties 2.2.1 Determination of Proximate Composition}

In order to minimize problems caused by insect infestation, fruit pulp was hand-scraped from the seeds and stored in an industrial freezer at $-20^{\circ} \mathrm{C}$ until the time of analyses. Prior to analyses, samples were inspected for non-plant materials, and all visible dirt and insectinfested parts of the fruits were removed [21]. Crude protein was determined by the micro kjeldahl method [22]. Available moisture content, ash content, crude fibre content and carbohydrate were estimated as described by the Association of official analytical chemists, AOAC [23], ASAE [24] and Pearson [25]. Crude fat was extracted by the soxhlet extraction method with petroleum ether $\left(40-60^{\circ} \mathrm{C}\right)$ for 8 hours $[26,27]$.

\subsubsection{Determination of Mineral Composition}

Some mineral elements in the Dialium guineense fruit pulp (yellow portion) comprising sodium, magnesium, phosphorus, calcium and iron were determined according to the method of Shahidi et al. [28] and Hacıseferog ulları et al. [29]. Vitamin C was determined by the method described by Pearson [25] while $\mathrm{pH}$ values of the solutions of the fruit pulp was measured using an HI $8521 \mathrm{pH}$ meter (Hanna Instruments, Woonsocket, RI, USA).

\subsection{Determination of Mechanical Properties of Unshelled} and Shelled Dialium guineense Fruit

Mechanical properties such as bio-yield force, rupture force, deformation at rupture point, deformation ratio at rupture point, compressive strength and total strain energy of Dialium guineense fruit were evaluated using unshelled and kernel parts of the fruit. Samples of the fruit were loaded across each of the length (L); width, perpendicular to the length (W); and thickness, perpendicular to the length and width (T). This was done by means of a UK- made Universal Testing Machine (Monsanto Tensometer A220 - 9).

\subsubsection{Determination of bio-yield force}

The bio-yield force (N) is the force at which the sample begins to fail. This is the force at which the material yields. Further application of force beyond the bio-yield force ruptures the sample.

\subsubsection{Determination of rupture force}

The rupture force, $F_{R}(\mathrm{~N})$ is the minimum force required to break the sample. Rupture force is expressed as the peak force in a force - deformation curve.

\subsubsection{Determination of deformation at rupture point}

Deformation at rupture point, $R_{D P}(\mathrm{~m})$ is the deformation at loading direction. 


\subsubsection{Determination of deformation ratio at rupture point}

Deformation ratio at rupture point, $R_{D R}$ is the axial strain at rupture point of the sample. It was calculated as ratio of deformation at rupture point to the dimension of the sample in loading direction. It was calculated with the expression in equation (1)

$$
R_{D R}=\frac{R_{D P}}{\operatorname{Lor} W \text { or } T}
$$

\subsubsection{Determination of Compressive Strength}

Compressive strength was calculated as the rupture force divided by the area (A) in contact with the fruit. Compressive strength, $\mathrm{H}\left(\mathrm{N} \mathrm{m}^{-2}\right)$ is the ratio of rupture force to the area (A) in contact with the fruit. It was calculated using equation (2).

$$
H=\frac{F_{R}}{A}
$$

\subsubsection{Determination of Total Strain Energy}

Energy for rupture, $E_{R}(\mathrm{~N} \mathrm{~m})$ is the energy needed to rupture the sample, which was determined from the area under the curve between the initial point and the rupture point. It was also calculated as the product of rupture force and deformation at rupture point as expressed in equation (3).

$$
E_{R}=F_{R} \times R_{D P}
$$

\section{RESULTS AND DISCUSSION}

\subsection{Chemical Properties}

Chemical properties of Dialium guineense fruit pulp (edible portion of the fruit) are presented in Table 1.

\subsubsection{Proximate Composition}

The proximate composition (\%) for the pulp of Dialium guineense fruit (edible yellow portion) which include crude protein (CP), moisture content (MC), ash content (AC), crude fibre content (CFC), crude fat (CF) and carbohydrate (CB) were determined as 9.378\%, $19.038 \%$ (wb), $2.446 \%, 4.574 \%, 5.218 \%$ and $75.03 \%$ respectively. Coulter and Lorenz [30] in a previous study determined the proximate composition of quinoa seeds which ranges from $10-18 \%$ for crude protein, from 4.5 $8.75 \%$ for crude fat, from $54.1-64.2 \%$ for carbohydrates, from 2.4 to $3.65 \%$ for ash and from $2.1-4.9 \%$ for crude fibre content. The value for crude protein was low, but slightly above the range of values reported by Adeola and Aworh [21] for Dialium guineense from different locations in Nigeria. However, it was almost the same value with the result of $9.2 \%$ reported by FAO [31]. According to Essienet al. [32], Dialium guineense fruits are generally not considered as excellent sources of proteins. Dialium guineense fruit pulp is also low in moisture content because they are normally harvested dry, though higher than the unshelled and kernel of the fruit. This result is within the range of values reported by Adeola and Aworh [21], but lower than the values of $22.6 \%$ and $31 \%$ reported by Leung and Flores [33] and FAO [31] respectively. Represented in a pie chart (Figure $2)$, carbohydrate (CB) has the highest percentage composition, followed by moisture content (MC), crude protein (CP), crude fat (CF), crude fibre content (CFC) and ash content (AC). The crude fibre content value was $22.47 \%$ below the value reported by Saka and Msonthi [34] and within the range of values of 2.4-4.7\% reported by Adeola and Aworh [21], for Dialium guineense fruit pulp from different locations in Nigeria.

Table 1. Chemical properties of Dialium guineense fruit pulp

\begin{tabular}{lcccc}
\hline Property & No. of Replication & Range & Mean & Standard deviation \\
\hline Proximate Composition (\%) & & & & \\
Crude Protein (CP) & 5 & $9.34-9.42$ & 9.378 & 0.033 \\
Moisture Content (MC)(wb) & 5 & $16.914-24.315$ & 19.038 & 1.522 \\
Ash Content (AC) & 5 & $2.35-2.6$ & 2.446 & 0.102 \\
Crude Fibre Content (CFC) & 5 & $4.5-4.63$ & 4.574 & 0.051 \\
Crude Fat (CF) & 5 & $5.1-5.34$ & 5.218 & 0.101 \\
Carbohydrate (CB) & 5 & $74.5-75.75$ & 75.03 & 0.484 \\
Mineral Composition (g kg-1) & & & & 0.0279 \\
Sodium & & & 3.199 & 0.1252 \\
Magnesium & 5 & $2.78-3.06$ & 2.902 & 0.0201 \\
Phosphorus & 5 & $0.42-0.52$ & 0.491 & 0.0131 \\
Calcium & 5 & $0.49-0.522$ & 0.5102 & 0.0011 \\
Iron & 5 & $0.122-0.125$ & 0.123 & 0.0051 \\
Vitamin C & 5 & $0.32-0.3318$ & 0.3262 & 0.05 \\
& 5 & & & 3.85 \\
\hline pH Value & & $3.8-3.9$ & \\
\hline
\end{tabular}




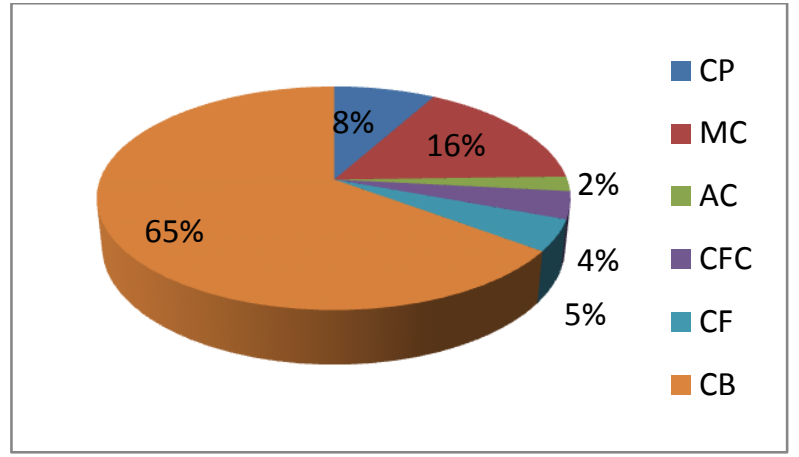

Figure 2. Percentage proximate composition of Dialium guineense fruit pulp

Different researchers have also reported on the crude fat and carbohydrate content of Dialium guineense fruit pulp with slightly varying values [21, 31, 33-35]. Variations in the reported values of proximate composition of Dialium guineense fruit pulp may be due to differences in the soil, climatic conditions, geographical condition and relative humidity of the surrounding atmosphere as well as cultural practices [21, 36, 37].

Benero et al. [38] had earlier reported differences in cultural practices in the handling of Dialium guineense fruits. According to Beneroet al. [38]; Krithika and Radhai Sri [39]; and Sadik[40], matured Dialium guineense fruits are left to dry, at different rate on trees till the next harvesting season.

Considering the proximate composition, Dialium guineense fruit pulp is therefore recommended for children and people with hypoglycaemia. The fruit pulp contains vitamin C $\left(0.3262 \mathrm{~g} \mathrm{~kg}^{-1}\right)$ which acts as a good source of nutrient for humans and animals but not as much as is generally acclaimed. The importance of vitamin $\mathrm{C}$ rest on its antioxidant power as well as its ability for inhibiting the ominous effect of free radicals on the DNA [41-43]. It is also indispensable for iron absorption, cloves repair and blood vessels formation via collagen synthesis. Any food poor in vitamin C is associated with fatigue [44] and immunodeficiency [45]. The value for $\mathrm{pH}$ was $3.85 \pm 0.05$. This indicates that the pulp of the fruit is acidic, which clearly agrees with the result of Adeola and Aworh [21].

\subsubsection{Mineral Composition}

The percentage mineral composition of sodium, magnesium, phosphorus, iron, calcium and vitamin $\mathrm{C}$ as shown in Figure 3 were 42\%, 38\%, 7\%, 2\%, 7\% and 4\% respectively. The mineral composition $\left(\mathrm{g} \mathrm{kg}^{-1}\right)$ for Dialium guineense fruit pulp indicates that sodium, magnesium, phosphorus, iron and calcium were $3.199 \mathrm{~g}$ $\mathrm{kg}^{-1}, 2.902 \mathrm{~g} \mathrm{~kg}^{-1}, 0.491 \mathrm{~g} \mathrm{~kg}^{-1}, 0.123 \mathrm{~g} \mathrm{~kg}^{-1}$, and $0.5102 \mathrm{~g}^{-}$

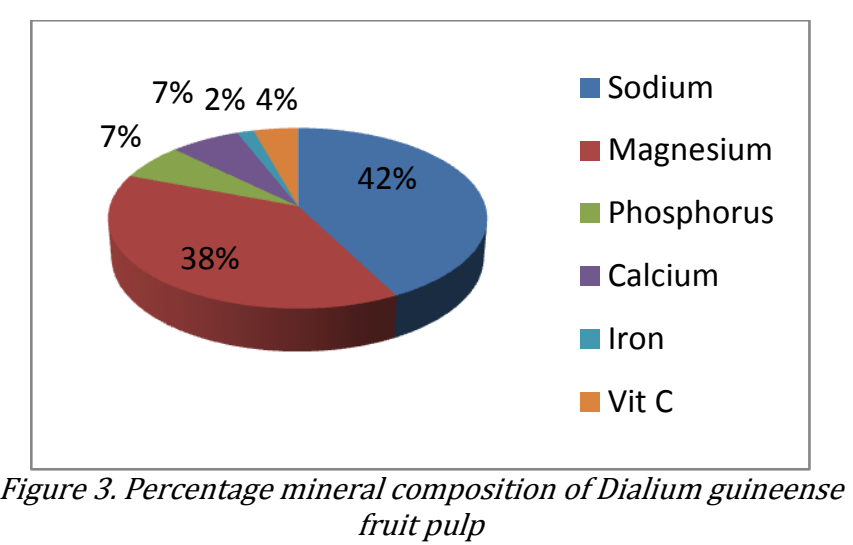

$\mathrm{kg}^{-1}$ respectively. Adepoju [46] reported slightly higher values for sodium (3.9 $\left.\mathrm{g} \mathrm{kg}^{-1}\right)$ and magnesium $\left(3.0 \mathrm{~g} \mathrm{~kg}^{-1}\right)$ and slightly lower values for phosphorus $\left(0.429 \mathrm{~g} \mathrm{~kg}^{-1}\right)$ and calcium $\left(0.47 \mathrm{~g} \mathrm{~kg}^{-1}\right)$. According to Kadri et al. [47], these minerals are essential in numerous biological functions and are very important for health. Calcium is needed for ossification, muscular contraction and blood coagulation [48]. As for magnesium, it cooperates with calcium for muscular contraction and blood coagulation. It is a co-factor for several enzymes [49]. Iron content of the fruit is a good means of preventive struggle against anemia. This result shows that Dialium guineense fruit pulp is rich in most of the minerals.

Of the entire Dialium guineense fruit, only the pulp (edible yellow portion) was investigated for proximate and mineral composition because it is the most valuable of all the portions, in terms of consumption, industrial, pharmaceutical and health purposes.

\subsection{Mechanical Properties}

Mechanical properties of unshelled and kernel of Dialium guineense fruit are presented in Tables 2 and 3 respectively.

\subsubsection{Bio-yield force}

The unshelled Dialium guineense fruit, loaded across the width has the highest bio-yield force $(32.091 \mathrm{~N})$ when compared with loading across the length $(19.394 \mathrm{~N})$ and across the thickness $(14.569 \mathrm{~N})$ as shown in Figure 4. The highest bio-yield force for the fruit kernel across the thickness was $58.275 \mathrm{~N}$, compared with the width $(37.0125 \mathrm{~N})$ and the length $(24.4125 \mathrm{~N})$. This means that it takes the highest force for unshelled Dialium guineense fruit to yield across the width and least force to yield across the thickness. For the fruit kernel, the highest force is needed for the fruit to yield across the thickness while the least force is needed across the fruit length (Figure 4). 
Table 2. Mechanical properties of unshelled Dialium guineense fruit

\begin{tabular}{|c|c|c|c|c|c|}
\hline Properties & No of Replications & $\begin{array}{l}\text { Loading } \\
\text { Direction }\end{array}$ & Range & Mean & $\begin{array}{l}\text { Standard } \\
\text { Deviation }\end{array}$ \\
\hline \multirow{3}{*}{$\begin{array}{l}\text { Bio-yield Force } \\
(\mathrm{N})\end{array}$} & 4 & Length & $17.325-22.05$ & 19.394 & 1.9818 \\
\hline & 4 & Width & $30.713-34.65$ & 32.091 & 1.7460 \\
\hline & 4 & Thickness & $12.6-15.75$ & 14.569 & 1.5079 \\
\hline \multirow{3}{*}{$\begin{array}{l}\text { Rupture Force } \\
\text { (N) }\end{array}$} & 4 & Length & $25.2-31.5$ & 28.744 & 3.2469 \\
\hline & 4 & Width & $40.95-50.4$ & 44.888 & 4.1671 \\
\hline & 4 & Thickness & $31.5-47.25$ & 38.981 & 6.7284 \\
\hline \multirow{3}{*}{$\begin{array}{l}\text { Deformation at Rupture Point } \\
\text { (m) }\end{array}$} & 4 & Length & $0.002-0.0023$ & 0.0021 & 0.0001 \\
\hline & 4 & Width & $0.002-0.0023$ & 0.0021 & 0.0001 \\
\hline & 4 & Thickness & $0.0025-0.0035$ & 0.0028 & 0.0005 \\
\hline \multirow{3}{*}{$\begin{array}{l}\text { Deformation Ratio at Rupture } \\
\text { Point }\end{array}$} & 4 & Lenght & $0.1149-0.1293$ & 0.1203 & 0.0069 \\
\hline & 4 & Width & $0.125-0.1406$ & 0.1328 & 0.0090 \\
\hline & 4 & Thickness & $0.3086-0.4321$ & 0.3472 & 0.0584 \\
\hline \multirow{3}{*}{$\begin{array}{l}\text { Compressive Strength }\left(10^{4}\right)(\mathrm{N} \\
\left.\mathrm{m}^{-2}\right)\end{array}$} & 4 & Length & $5.4427-6.8034$ & 6.208 & 0.701 \\
\hline & 4 & Width & $8.8444-10.886$ & 9.695 & 0.9 \\
\hline & 4 & Thickness & $6.8034-10.205$ & 8.419 & 1.453 \\
\hline \multirow{3}{*}{$\begin{array}{l}\text { Total Strain } \\
\text { Energy (N m) }\end{array}$} & 4 & Length & $0.0504-0.0709$ & 0.0589 & 0.0091 \\
\hline & 4 & Width & $0.0819-0.1134$ & 0.0958 & 0.0149 \\
\hline & 4 & Thickness & $0.079-0.1433$ & 0.1101 & 0.0304 \\
\hline
\end{tabular}

Table 3. Mechanical properties of Dialium guineense fruit kernel

\begin{tabular}{|c|c|c|c|c|c|}
\hline Properties & $\begin{array}{l}\text { No of } \\
\text { Replications }\end{array}$ & $\begin{array}{l}\text { Loading } \\
\text { Direction }\end{array}$ & Range & Mean & $\begin{array}{l}\text { Standard } \\
\text { Deviation }\end{array}$ \\
\hline \multirow{3}{*}{ Bio-yield Force (N) } & 4 & Length & $18.9-28.35$ & 24.4123 & 3.9637 \\
\hline & 4 & Width & $34.65-37.8$ & 37.0125 & 1.575 \\
\hline & 4 & Thickness & $53.55-63$ & 58.257 & 4.0666 \\
\hline \multirow{3}{*}{ Rupture Force (N) } & 4 & Length & $31.5-37.8$ & 34.65 & 2.572 \\
\hline & 4 & Width & $50.4-69.3$ & 60.6375 & 7.875 \\
\hline & 4 & Thickness & $81.9-97.65$ & 90.5625 & 6.9847 \\
\hline \multirow{3}{*}{ Deformation at Rupture Point (m) } & 4 & Length & $0.0018-0.0025$ & 0.0022 & 0.0003 \\
\hline & 4 & Width & $0.002-0.0026$ & 0.0024 & 0.0003 \\
\hline & 4 & Thickness & $0.002-0.0033$ & 0.0025 & 0.0006 \\
\hline \multirow{3}{*}{$\begin{array}{l}\text { Deformation Ratio at Rupture } \\
\text { Point }\end{array}$} & 4 & Lenght & $0.2273-0.3247$ & 0.2841 & 0.0409 \\
\hline & 4 & Width & $0.2778-0.3646$ & 0.3299 & 0.0375 \\
\hline & 4 & Thickness & $0.5556-0.9028$ & 0.6858 & 0.1662 \\
\hline \multirow{3}{*}{$\begin{array}{l}\text { Compressive Strength }\left(10^{4}\right)\left(\mathrm{N} \mathrm{m}^{-}\right. \\
\left.{ }^{2}\right)\end{array}$} & 4 & Length & $34.317-41.1764$ & 37.745 & 2.802 \\
\hline & 4 & Width & $54.9019-75.490$ & 66.054 & 8.578 \\
\hline & 4 & Thickness & $89.2156-106.37$ & 98.652 & 7.609 \\
\hline \multirow{3}{*}{$\begin{array}{l}\text { Total Strain } \\
\text { Energy (N m) }\end{array}$} & 4 & Length & $0.0551-0.0866$ & 0.0762 & 0.0145 \\
\hline & 4 & Width & $0.1008-0.1819$ & 0.1456 & 0.0341 \\
\hline & 4 & Thickness & $0.1638-0.2867$ & 0.2239 & 0.0572 \\
\hline
\end{tabular}

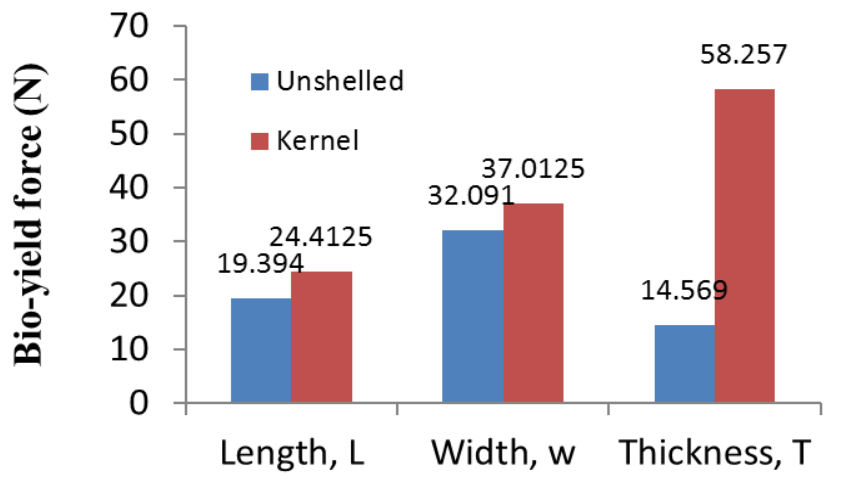

Loading direction

Figure 4: Bio-yield force of unshelled and kernel of Dialium guineense fruit across different loading directions.

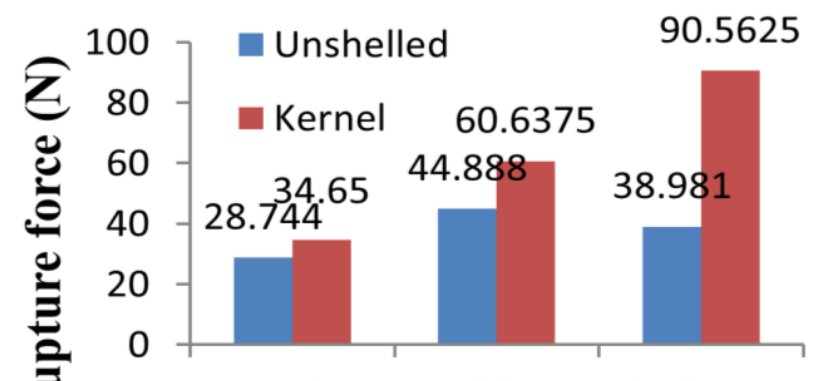

Length, L Width, W Thickness,

$\mathrm{T}$

\section{Loading direction}

Figure 5. Rupture force of unshelled and kernel of Dialium guineense fruit across different loading directions. 


\subsubsection{Rupture Force}

The highest rupture force for the unshelled fruit occurred across the width (44.888 N), followed by the thickness $(38.981 \mathrm{~N})$ and the length $(28.744 \mathrm{~N})$ as shown in Figure 5. This implies that unshelled Dialium guineense fruit is strongest across the width but weakest across the length. It required least force to rupture the fruit across the length, followed by the thickness and then across the width. For the fruit kernel, the thickness has the highest rupture force $(90.5625 \mathrm{~N})$ when compared with the width $(60.6375 \mathrm{~N})$ and length (34.65 $\mathrm{N})$. This implies that the kernel of fruit is strongest across the thickness, weaker across the width, and weakest across the length. It required the least force to crack the fruit across the length followed by the width, and the thickness. Figure 5 suggests that it requires more force to rupture the kernel of the fruit than the unshelled fruit.

\subsubsection{Deformation at Rupture Point}

Values of deformation at rupture point across the unshelled fruit length, width and thickness were 0.0021 $\mathrm{m}, 0.0021 \mathrm{~m}$ and $0.0028 \mathrm{~m}$ respectively as shown in Figure 6. The fruit kernel had values for deformation at rupture across the length, width and thickness as 0.0022
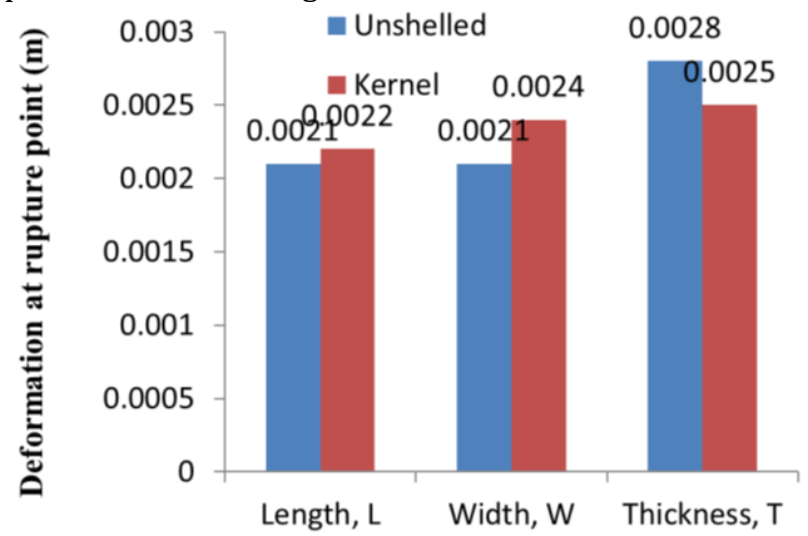

\section{Loading direction}

Figure 6. Deformation at rupture point of unshelled and kernel of Dialium guineense fruit across different loading directions.
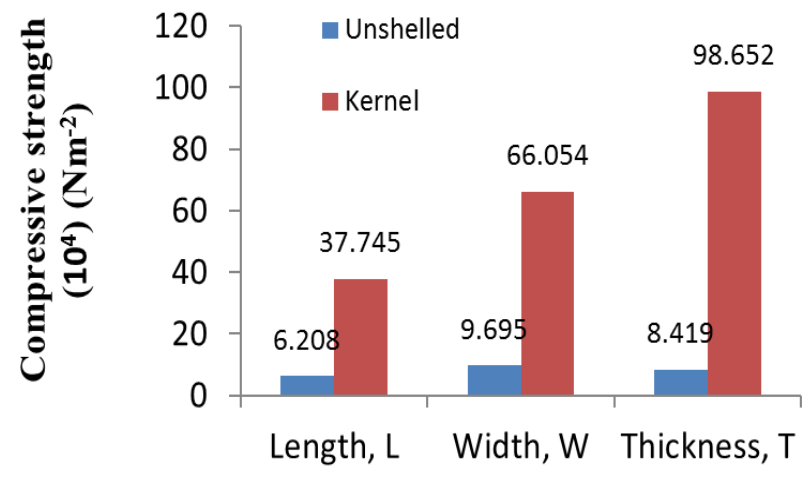

\section{Loading direction}

Figure 8: Compressive strength of unshelled and kernel of Dialium guineense fruit across different loading directions. $\mathrm{m}, 0.0024 \mathrm{~m}$ and $0.0025 \mathrm{~m}$ respectively. This implies that the unshelled Dialium guineense fruit has the highest deformation at rupture point across the thickness and the least across the length. The fruit kernel had generally higher values of deformation at rupture point than the unshelled. This points out that the unshelled fruit need lower compression to rupture than the kernel.

\subsubsection{Deformation Ratio at Rupture Point}

In Figure 7, values of deformation ratio at rupture point across unshelled Dialium guineense fruit length, width and thickness were $0.1203,0.1328$ and 0.3472 respectively. For the fruit kernel, they were 0.2841, 0.3299 and 0.6858 across the length, width and thickness respectively.

\subsubsection{Compressive Strength}

The compressive strength for the unshelled Dialium guineense fruit across the length, width and thickness were $6.208 \times 10^{4} \mathrm{~N} \mathrm{~m}^{-2}, 9.695 \times 10^{4} \mathrm{~N} \mathrm{~m}^{-2}$ and $8.419 \times 10^{4}$ $\mathrm{N} \mathrm{m}^{-2}$ respectively (Figure 8 ). Therefore loading across the width required the highest compressive strength when compared with loading across the thickness and length.

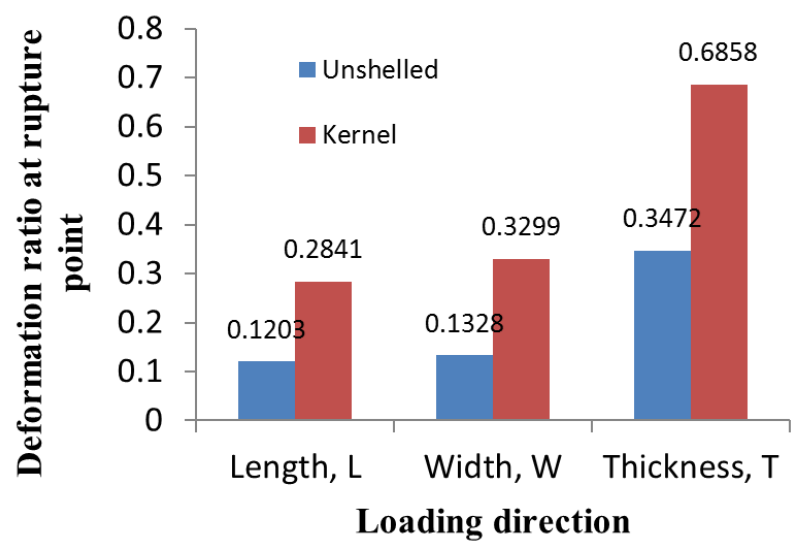

Figure 7. Deformation ratio at rupture point of unshelled and kernel of Dialium guineense fruit across different loading directions.

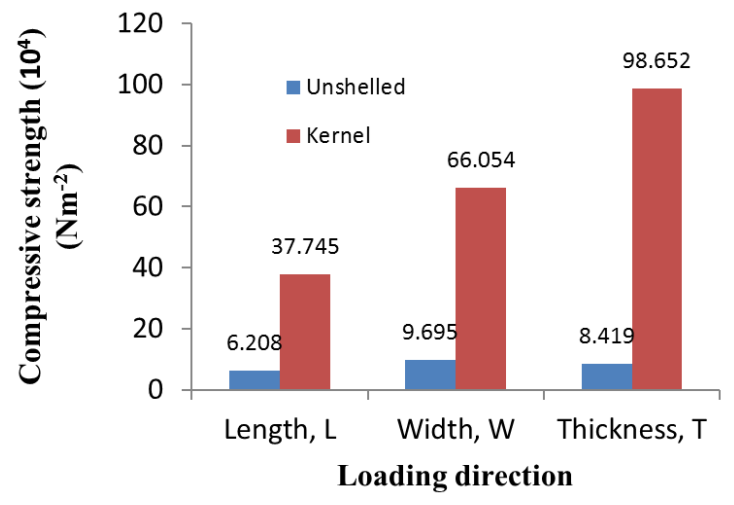

Figure 9: Total strain energy of unshelled and kernel of Dialium guineense fruit across different loading directions.

Vol. 36, No. 1, January 2017 
The values of compressive strength for the fruit kernel were $37.745 \times 10^{4} \mathrm{~N} \mathrm{~m}^{-2}, 66.054 \times 10^{4} \mathrm{~N} \mathrm{~m}^{-2}$ and 98.652 $\times 10^{4} \mathrm{~N} \mathrm{~m}^{-2}$ across the length, width and thickness respectively. Therefore, loading across the thickness had the highest compressive strength while the length had the least for the fruit kernel. The compressive strength values for the kernel were quite higher than that for the unshelled fruit. This could be due to the hard and viscous nature of the fruit kernel.

\subsubsection{Total strain energy}

The total strain energy required in breaking the unshelled fruit across its length, width and thickness were $0.0589,0.0958$ and $0.1101 \mathrm{~N} \mathrm{~m}$, while total strain energy needed for breaking kernel of fruit across the same geometric dimensions was 0.0762, 0.1456 and $0.2239 \mathrm{~N} \mathrm{~m}$ (Figure 9). Measurement of total strain energy across different dimension is important because deshelling efficiency depends on the orientation of the sample on the crushing bars and on the separation of unit mass [50]. It implies that it will be most efficient to shell Dialium guineense fruit across fruit length. In a related work, Sirisomboon et al. [51] reported values for rupture force, deformation at rupture point, deformation ratio at rupture point and total strain energy for fruit, nut and kernel of Jatropha as $135.39 \mathrm{~N}, 4.36 \mathrm{~mm}, 0.15$ and $300.88 \mathrm{~N} \mathrm{~mm} ; 146.63 \mathrm{~N}, 2.10 \mathrm{~mm}, 0.22$ and $124.44 \mathrm{~N} \mathrm{~mm}$; and $60.23 \mathrm{~N}, 1.74 \mathrm{~mm}, 0.23$ and $51.61 \mathrm{~N} \mathrm{~mm}$ respectively.

The mechanical properties of the unshelled and kernel of Dialium guineense fruit were only investigated across three different loading directions as these are the forms where mechanical applications for fruit processing, storage, handling, product quality evaluation, and transportation are most vital.

\section{CONCLUSIONS}

Crude protein, ash, crude fibre, crude fat, and carbohydrate contents of Dialium guineense fruit pulp were found to be $9.4 \%, 2.5 \%, 5.7 \%, 5.2 \%$, and $75 \%$ respectively at moisture content of $19 \% \mathrm{wb}$. Sodium, magnesium, phosphorus, calcium, iron and vitamin $\mathrm{C}$ contents were $3.2 \mathrm{~g} \mathrm{~kg}^{-1}, 2.9 \mathrm{~g} \mathrm{~kg}^{-1}, 0.4 \mathrm{~g} \mathrm{~kg}^{-1}, 0.5 \mathrm{~g} \mathrm{~kg}^{-1}$, $0.1 \mathrm{~g} \mathrm{~kg}^{-1}$ and $0.3 \mathrm{~g} \mathrm{~kg}^{-1}$ in composition respectively. Least energy and force were required to rupture and crack the unshelled fruit and kernel of velvet tamarind (Dialium guineense) across their lengths. Mechanical cracking of unshelled fruit and kernel of Dialium guineense should not be done across their geometric width or thickness. Cracking both the kernel and unshelled fruit is easier across the length.

\section{REFERENCES}

[1] Arogba, S.S., Ajiboro, A. A. and Odukwe, I.J. "A physico-chemical study of Nigerian velvet tamarind, Dialium guineense L. Fruit". J. Sc. Food Agric., Vol. 66, pp 533-534. 2006,

[2] Nwosu, M.O. "Plant resources used by traditional women as herbal medicine and cosmetics in Southwest Nigeria". Arzte fur Natur Fahr, Vol. 41, pp 11. 2000,

[3] Akinpelu, A. D., Awotorebo, I. O. Agunbiade, O. M., Aiyegoro, A. O., and Okoh, I. A. "Anti-Vibrio and preliminary phytochemical characteristics of crude methanolic extractsof the leaves of Dialiumguineense (Wild)". Journal of Medicinal Plants Research, Vol. 5, Number 11, pp 2398-2404. 2011.

[4] Obasi, N. E., Okorocha, C., and Orisakwe, O. F. "Production and evaluation of velvet tamarind (Dialiumguineense wild) candy". European journal of food science and technology, Vol. 1, Number 1, pp 1-8. 2013,.

[5] Balogun, M. E, Oji, J. O. Besong, E. E., and Umahi, G. 0 . "Evaluation of the anti-ulcer properties of aqueous leaf extract of Dialiumguineense (Velvet Tamarind) on experimentally induced ulcer models in rats". International Journal of Development Research, Vol. 3, Issue 10, pp 106110. 2013.

[6] Bero, J. H., Ganfon, M, Jonville, C., Frederich, M., Gbaguidi, F., De, M. P., Moudachirou, M. and Quetin, L. J. "In vitro antiplasmodial activity of plants used in Benin in traditional medicine to treat malaria". J. Ethnopharmacol, Vol. 122, Issue 3, pp 439-444. 2009.

[7] Ewedje, E. B. K. and Tandjiekpon, A. "Dialiumguineense, velvet tamarind. Conservation and Sustainable Use of Genetic Resources of Priority Food Tree Species in sub-Saharan Africa". Bioversity International, Rome. Italy, 2011.

[8] Sreenarayana, V. V., Visvanathan, R., and Subramanijam, V. "Physical and thermal properties of soybean". Journal of Agricultural Engineering, Vol. 25, Issue 4, pp 25-31. 1988.

[9] Deshpande, S. D., Bal, S., and Ojha, T. P.“Physical properties of soybean". Journal of Agricultural Engineering Research, Vol. 56, Issue 2, pp 89-98. 1993.

[10] Oje, K.and Ugbor, E. C. "Some physical properties of oil bean seed". Journal of Agricultural Engineering Research, Vol. 50, Issue 4, pp 305-313. 1991.

[11] Visvanathan, R., Palanisamy, P. T., Gothandapani, L., andSreenarayanan, V. V. "Physical properties of neem nut" .Journal of Agricultural Engineering Research, Vol. 63, 1996, pp 19-26. 1996.. 
[12] Suthar, S. H. and Das, S.K. "Some physical properties of karingda [Citrulluslanatus (Thumb) Mansf] seeds". Journal of Agricultural Engineering Research, Vol. 65,, pp 15-22. 1996.

[13] Singh, K. K. and Goswami, T. K."Physical properties of cumin seed". Journal of Agricultural Engineering Research, Vol. 64, pp 93-98. 1996,

[14] Carman, K. "Some physical properties of lentil seeds". Journal of Agricultural Engineering Research, Vol. 63, pp 87-92. 1996.

[15] Gupta, R. K. and Das, S.K. "Physical properties of sunflower seeds". Journal of Agricultural Engineering Research, Vol. 66, pp 1-8. 1997,

[16] Chandrasekar, V. and Viswanathan, R. "Physical and thermal properties of coffee". Journal of Agricultural Engineering Research, Vol. 73, Issue 2, pp 227-234. 1999.

[17] Nimkar, P. M. and Chattopadhyaya, P. K. "Some physical properties of green gram". Journal of Agricultural Engineering Research, Vol. 80, Issue 2, pp 183-189. 2001.

[18] Konak, M., Arman, K.C., and Aydin, C.“Physical Properties of Chick Pea Seeds". Biosystems Engineering, Vol. 82, Issue 1, pp 73-78. 2002,

[19] Asoiro, F. U. and Ani, A. O. "Determination of some physical properties of African yam beans". Pacific Journal of Science and Technology, Vol. 12, Number 1, 2011, pp 374-380. 2011.

[20] Hu, M., Dong, Q., B. Liu, B., Opara, U. L., and Chen, L. "Estimating blueberry mechanical properties based on random frog selected hyperspectral data". Postharvest Biology and Technology, Vol. 106, pp 1-10. 2015.

[21] Adeola, A. A. and Aworh, O. C. "A comparative evaluation of the chemical properties of wild tamarind (Tamarind usindicaL.) fruits in Nigeria". Food, Vol. 6, Issue 1, p 49-57. 2012,

[22] Cheikh-Rouhou, S., Besbes, S., Hentati, B., Blecker, C., Deroanne, C., and Attia, H. "Nigella sativa L.: Chemical composition and physicochemical characteristics of lipid fraction". Food Chemistry, Vol. 101,,pp 673-681. 2007.

[23] AOAC. Official methods of analysis (15th ed.). Washington, DC: Association of Official Analytical Chemists, 2010.

[24] ASAE. Standard S 358.2, Moisture Measurement of Grain and Seeds.37th Ed. St.Joseph, 1983.

[25] Pearson, D. A. The Chemical analysis of Foods.( $7^{\text {th }}$ ed). Churchill Living Stone, Eduinburgh, 1976.

[26] James, C. S. "Principles and Techniques used in food analysis: In analytical chemistry of foods", Blackie Academic and Professionals-an imprint of Champion and Hall, London, pp 6-15. 1995.
[27] Ghirardello, D., Contessa, C., Valentini, N., Zeppa, G., Rolle, L., Gerbi, V., and Botta, R. "Effect of storage conditions on chemical and physical characteristics of hazelnut (Corylus avellana L.)".Postharvest Biology and Technology, Vol. 81, pp 37-43. 2013.

[28] Shahidi, F., U. D. Ghavan, A. D. Bal and D. B. Mckenzie. "Chemical composition of beach pea A (Lathyrusmaritimus L.).Plant Parts" Foods Chem., Vol. 64, pp 39-44. 1999.

[29] Hacıseferogullarıa, H., Gezer, I., Ozcan, M. M. and MuratAsma, B."Post harvest chemical and physicalmechanical properties of some apricot varieties cultivated in Turkey". Journal of Food Engineering, Vol. 79, pp 364-373. 2007.

[30] Coulter, L. and Lorenz, K. "Quinoa composition, nutritional value, food applications". LebensmittelWissenschaft und-Technologies, Vol. 23, pp 203207. 1990,

[31] FAO. Traditional food plants.FAO Food and Nutrition Paper 42, Food and Agriculture Organization of the United Nations, Rome, 1988.

[32] Essien A.I, Ebana, R. U. B., and Udo, H.B... “Chemical evaluation of pod and pulp of the fluted pumpkin (Telfairaoccidentalis) fruit". Food Chemistry, 45: pp 175- 178. 1992.

[33] Leung, W. W. and Flores, M. Tabla de composición de alimentos para usoenAmérica Latina / Table of food composition for use in Latin America. Guatemala; INCA P;jun. pp 158. 1961.

[34] Saka, J. D. K and Msonthi, J. D. "Nutritional value of edible fruits of indigenous wild trees in Malawi. Forest Ecology and Management. Vol. 64, Issue (2-3),pp 245-248. 1994.

[35] Wenkam, N. S., and Miller, C. D. "Composition of Hawaii fruits". Hawaii Agriculture Experimental Station Bulletin, Vol.135, pp 65-75.1965.

[36] Gunasena, H. P. M. and Hughes, A. Tamarind. International Centre for Underutilised Crops, Southampton, pp 182. 2000.

[37] Wilkes, M. A., Seung, D., G. Levavasseur, G., Trethowan, R. M., and Copeland, L." Effects of soil type and tillage on protein and starch quality in three related wheat genotypes". Cereal Chemistry, Vol.87, pp 95-99. 2010,.

[38] Benero, J. R., Collazo de Rivera, A. L., and Georage, L. M. I."Studies on the preparation and shelf life of soursop, tamarind and blended soursop-tamarind soft drinks". Journal of the Agricultural University (Puerto Rico), Vol. 58 pp 58-99. 1974,.

[39] Krithika, V and Radhai Sri, S. "Value added products from tamarind". Available online: www.technopreneur.net/information desk/sciencetechmagazin e/ Accessed on November 7, 2007. 
[40] Sadik, H.A. "The nutritional value of Poha Beer (Tamarind fruit drink) and its social usage in Tamale metropolis". Pakistan Journal of Nutritions, 9: pp. 797-805. 2011.

[41] Vojdani, A., Bazargan, M., Vojdani, E., and Wright, J. New evidence for antioxidant properties of vitamin C. Cancer Detection and Prevention, Vol. 24, Issue 6, 2000, pp 508-523. 2000.

[42] Laight, D. W., Carrier, M. J., and Anggard, E. E. "Antioxidants, diabetes and endothelial dysfunction". Cardiovascular Research, Vol. 47, pp 457-464. 2000,.

[43] Masaki, H. "Role of antioxidants in the skin: antiaging effects". Journal of Dermatological Science, Vol. 58, Issue 2, pp 8590.DOI 101016. 2010,

[44] Suh, S. Y., Bae, W. K., Ahn, H. Y., Choi, S. E., Jung, G.C., and Yeom, C. H. "Intravenous Vitamin C administration reduces fatigue in office workers: a double-blind randomized controlled trial". Nutrition Journal, Vol. 11, pp 7. 2012,.

[45] Harakesh, S., Jariwalla, R., and Pauling, L. "Suppression of human immunodeficiency virus replication by ascorbate in chronically and acutely infected cells". Proceedings of the National Academy of Sciences USA, Vol. 87, Number 18, pp 7245-7249. 1990.
[46] Adepoju, 0. T. "Proximate composition and micronutrient potentials of three locally available wild fruits in Nigeria". African Journal of Agricultural Research Vol. 4, Number 9, pp 887-892

[47] Kadri, N., Khettal, B., Aid, Y., Kherfellah, S., Sobhi, W., and Barragan-Montero, V. 2015. "Some physicochemical characteristics of pinus (Pinushalepensis Mill. ,Pinuspinea L., Pinuspinaster and Pinuscanariensis) seeds from North Algeria, their lipid profiles and volatile contents". Food Chemistry, Vol. 188, pp 184-192, 2015,

[48] Wardlaw, G. and Smith, A. Contemporary Nutrition, a functional approach. 3rd edn. Publisher: Mc GrawHiller Science /Engineering/ Math, 2012.

[49] Rude, R. K. Magnesium. Encyclopedia of Dietary Supplements 2nd ed. New York, Informa Healthcare, 2010, pp 527-537.

[50] Shkelqim, K. and Joachim, M. "Determination of physical, mechanical and chemical properties of seeds and kernels of Jatropha curcas L". Industrial Crops and Products, Vol.32, , pp 129-138. 2010.

[51] Sirisomboon, P., Kitchaiya, P., Pholphos, T and Mahuttanyawanittch, W. "Physical and mechanical properties of Jatropha curcas L. fruits, nuts and kernels". Biosystems Engineering, Vol.97, pp 201207. 2007. 